\title{
Üniversite Öğrencilerinin Cinsel Mitlere İlişkin İnanç ve Tutumları*
}

\author{
University Students' Beliefs and Attitudes on Sexual Myths \\ Burcu Avcibay Vurgeci
}

' Dr.Öğr.Üyesi. Çukurova Üniversitesi Sağlık Bilimleri Fakültesi, Ebelik Bölümü, https://orcid.org/0000-0003-2467-5101

öz

Amaç: Bu çalışmanın amacı üniversite öğrencilerinin cinsel mitlere yönelik inanç ve tutumlarını belirlemektir.

Yöntem: Çalışmanın tasarımı tanımlayıcı niteliktedir. Veriler literatür taramasından sonra hazırlanan özgün bir anket formu ile toplanmıştır. Anket formu tanımlayıcı bilgiler, cinsellik ile ilgili bilgi kaynakları ve 25 maddelik disfonksiyonel cinsel inanış ifadelerini içermektedir. Cinsel mitleri içeren ifadeler katılıyorum/katılmıyorum tarzında değerlendirilmiştir. Çalışma 212 kadın 278 erkek üniversite öğrencisi ile gerçekleştirilmiştir.

Bulgular: Katılımcıların yaş ortalaması $21.44 \pm 1.89$ 'dur ve \%56.7'si erkektir. Cinsellik ile ilgili bilgi edinirken kadınlar çoğunlukla arkadaşlarına(\%52.4), erkekler ise çoğunlukla internete(\%60.8) başvurmaktadır. Mitlere inanma durumu ile cinsiyet, yaş, fakülte ve sınıf düzeyleri arasında istatistiksel olarak anlamlı bir ilişki olduğu belirlenmiştir. "Eğer iki insan birbirini seviyorsa cinsel ilişkiden zevk almasını da bilir" ve "Cinsellik doğaldır, öğrenilemez" hem erkeklerin hem de kadınların en çok onayladıkları mitlerdir. Kadınların en çok onaylamadıkları mit "Cinsellik penisin vajinaya girmesinden ibarettir" mitidir. Erkeklerin en çok onaylamadıkları mit ise "Kadınların cinsel ilişkiyi başlatması ahlaksızlıktır" mitidir.

Sonuç: Genç nüfus cinsel mitlere yaygın olarak inanmaktadır. Kazanılmış inanç mekanizları üzerinde köklü bir değiş̧im yaratmak oldukça güçtür. Doğru olmayan cinsel inanışların/mitlerin, sağlıklı bir cinsel yaşam ve partner ilişkisi üzerinde önemli etkileri vardır. Eğitim ile bu inanışlar üzerinde olumlu yönde bir etki sağlanabilir. Ancak, bu eğitime üniversite eğitiminden önce başlamalı ve yaşam boyu devam etmelidir.

Anahtar Kelimeler: Cinsel mitler, cinsel inanışlar, tutum, cinsellik

\section{ABSTRACT}

Objective: The aim of this study is to determine the beliefs and attitudes of university students towards sexual myhts.

Method: The design of the study is descriptive. The data were collected with a unique questionnaire which prepared by author after the literature review. The questionnaire includes descriptive information, sexual information sources and 25-item dysfunctional sexual belief statements. Statements containing sexual myths were evaluated as agree / disagree. The study was conducted with 212 female and 278 male university students.

Results: The average age of participants is $21.44 \pm 1.89$ and $56.7 \%$ of them are male. While obtaining information about sexuality, women mostly apply to friends (52.4\%) and men mostly use the internet (60.8\%). It is determined that there is a statistically significant relationship between myths believing status and gender, age, faculty and class level. "If two people love each other, they also know to get pleasure from sexual intercourse" and "Sexuality is natural, it can not be learned" are the most confirmed myths by both men and women. The most disapproved myth by women is the myth that "Sexuality is about the penetration of the penis into the vagina." The most disapproved myth by men is the myth that "Women initiate sexual intercourse is immoral."

Conclusion: The young population widely believes in sexual myths. It is very difficult to create a radical change on acquired belief mechanisms. Dysfunctional sexual beliefs/ sexual myths have important effects on a healthy sex life and partner relationship. Education can have a positive effect on these beliefs. However, this education should start before university education and continue throughout life.

Keywords: Sexual myths, sexual beliefs, attitudes, sexuality

*Lokman Hekim Dergisi, 2020; 10 (3): 392-403

DOI: 10.31020/mutftd. 720744

e-ISSN: 1309-8004, ISSN 1309-761X

Geliş Tarihi - Received: 15 Nisan 2020; Kabul Tarihi - Accepted: 17 Ağustos 2020

Iletişim - Correspondence Author: Burcu Avcıbay Vurgec <burcuavcibay@hotmail.com>

Etik Onay: Çukurova Üniversitesi Tıp Fakültesi Girişimsel Olmayan Klinik Araştırmalar Etik kurulu (50243401/2020-5) 


\section{Giriş}

Cinsellik, yaşam boyunca insan olmanın merkezinde yer alan ve cinsiyet, cinsiyet kimlikleri ve rolleri, cinsel yönelim, erotizm, istek, cinsel ilişki ve üremeyi kapsayan bir kavramdır. Bu çok boyutlu kavram, düşünce, fanteziler, arzular, inançlar, tutumlar, değerler, davranışlar, uygulamalar, roller ile ilişkilerde yaşanır ve ifade edilir. Cinsellik bu boyutların tümünü kapsıyor olsa da, hepsi her zaman tecrübe edilemez veya ifade edilemez. Çünkü biyolojik, psikolojik, sosyal, ekonomik, politik, kültürel, etik, yasal, tarihi, dini ve manevi pek çok dış faktörün etkileşimi tarafından etkilenir. ${ }^{1,2}$

Mit kavramı ise iki (en az) çağrışıma sahiptir. Bunlardan biri, tarih, din ve kültürle iç içe geçmiş ve insan davranışını yönlendiren ve anlam veren bir efsane ya da hikaye olarak mittir. ikincisi ise yanlış bir inanış-bir yalandır. ${ }^{3,4}$ Bir başka tanımla mit, insanın evrene, bireyin kendine ve başkalarına karşı farkındalığı ve tepkisi olan bir düşünce ve hissetme sürecini ortaya koyan bir ifade biçimidir. Korku ve isteklerin başka bir biçimde ifade edilemeyen ya da ortaya konulamayan somut ve dramatik bir formudur. ${ }^{5}$ Cinsel mitler ise, bilimsel kanıt olmadan, tartışmasız olarak doğru kabul edilen, cinsellik hakkındaki yanlış ve gerçek dışı kavramlara atıfta bulunur. ${ }^{6-8}$

Cinsellikle ilgili yanlış ve abartıı inanışlara birçok toplumda rastlanmakta, çeşitliliği benzerlik göstermekte ve toplum içinde genel kabul görmektedir. Tarihsel kökenler, felsefi gelenekler, aile yapıları ve kişilerarası ilişkisel farklılıklar cinsel aktiviteye ilişkin farkı inançların benimsenmesine yol açabilir. ${ }^{9}$ Bu bağlamda üniversiteler, farklı değerlere ve kültürel geçmişe sahip gençlerin bir araya geldiği ortamlardır. Türkiye gibi geleneksel toplumlarda cinsellik, baskılanan, açıkça konuşulmayan, ayıp görülüp üstü kapatılan ve tabu olarak görülebilen bir konu olabilmektedir. ${ }^{10,11}$ Bu sebeple informal bilgi kaynaklarına yönelim artmakta ve cinsellikle ilgili birçok eksik, yanlış ve/veya abartılı bilgiye ulaşılmaktadır. Bu yanlış bilgilenme sonucunda, bireylerde cinsellikle ilgili pek çok önyargı oluşturmaktadır. ${ }^{12}$ Tüm bunların yanında cinsel mitlerin çoğunlukla kadını küçümseyen, değersizleştiren bir yanı vardır. Cinsel yaşam ve cinsel haz adeta erkekler içindir ve kadınlar cinsel yaşamın tüketim mallarından ibarettir. Ancak cinsel inanışların ve mitlerin sadece kadınlara zarar verdiğini söylemek doğru değildir. Erkeği her zaman, her yerde, herkesle seks yapmakla görevlendirilen, duygularını ortaya koymayan bir seks makinesi olarak gören bu inanışlar sonuçta erkeklerin de cinsel yaşamlarını olumsuz etkiler, sevgi, aşk, şefkat, sıcaklık, yakınlık hissetmek gibi insani duygulardan uzaklaştırır. Kadını aşağılarken, erkeği mecbur kılarak, partnerleri birbirinden ayırır ve yabancılaştırır. ${ }^{13-15} \mathrm{Bu}$ inançların eleştirel olmayan ve koşulsuz kullanımı hem cinsellik hem de ilişkilerle ilgili gerçekçi olmayan beklentilere ve cinsel zorluklara yol açabilir. ${ }^{16}$

Cinsel mitlerin çoğu kez, cinsel işlev bozukluğunun zemin hazırlayıcı, tetikleyici veya sürdürücü etkenler olarak karşımıza çıktığı ifade edilmektedir. ${ }^{12,14,17,18}$ Bireyin cinsel alanda bilgisizliği, sadece cinsel işlev bozukluğuna değil aynı zamanda kendi ve karşı cinsi tanımayan, özgüveni eksik bireyler üretmekte ve yaşam kalitesinin azalmasına neden olabilmektedir. ${ }^{19-22}$

Üniversite formal bir eğitim kurumu olmasının yanında sosyal ve bilişsel düzeyde bireyleri geliştiren bir ortamdır. Türkiye nüfus verilerine göre 10-24 yaş arası genç bireylerin tüm nüfusun \%23.5'ini oluşturmaktadır. ${ }^{23}$ Güncel literatürde doğru olmayan cinsel inanışlar/mitler konusunda çalışmalar mevcut ancak öğrenci grupları ile yapılmış olanlar az sayıdadır. Türkiye'de yapılmış sınırlı sayıda çalışma mevcuttur ve yalnızca dört çalışmada fakülteler arası karşılaştıııma yapılmıştır. ${ }^{24-32}$ Bu çalışmanın amacı üniversite öğrencilerinin cinsel mitler konusundaki inanç ve tutumlarını belirlemektir ve Türkiye'nin güneyindeki bir üniversitesinin profilini yansıtan ilk çalışmadır. 


\section{Yöntem}

Tanımlayıcı nitelikte olan çalışmanın verileri, öğrencilerin eğitim dönemi içerisinde, Şubat-Nisan 2017 tarihleri arasında üç aylık sürede, gelişigüzel örnekleme yöntemi ile toplanmıştır. Araştırmanın evrenini çalışmanın yapıldığı üniversitenin lisans düzeyinde eğitim veren fakültelerinde birinci öğretimde kayıtlı olan öğrenciler, örneklemini ise dahil edilme kriterine uyan fakültelerde eğitim gören ve çalışmaya katılmayı kabul eden öğrenciler oluşturmuştur.

Çalışmanın yapıldığı dönemde üniversitenin, dahil edilme kriterine uygun toplam 12 fakültesi bulunmaktadır. Fakülte seçiminde, üniversitenin ders kataloğu derece programları menüsü incelenmiş ve cinsel sağlık ve üreme sağlığı konusuna özel dersi olmayan fakülteler çalışmanın hedef grubunu oluşturmuştur. Sağlık Bilimleri Fakültesi, seçmeli dersler arasında cinsel sağılık ve üreme sağlığı isimli dersin yer alması nedeniyle çalışma dışı bırakılmıştır. Çalışma bulguları, fakültelerden üçünün şehir merkezinin dışındaki ilçelerde olması, birisinin kayıtlı öğrenci sayısının istatistiksel olarak değerlendirmeye uygun olmaması ve bir fakültenin çalışma izni vermemesi nedeniyle 7 fakülteyi temsil etmektedir. Çalışmanın yapıldığı 7 fakültenin toplam öğrenci sayısı yaklaşık 10 bindir. Örneklem büyüklüğü olarak gelişigüzel örnekleme yöntemi ile 1000 olarak belirlenmiştir. ${ }^{33}$ Tahmini katılım oranı \% 70 alınmış ve en az 700 öğrenciye ulaşılması hedeflenmiştir. Ancak gönüllü katılım oranının beklenenden düşük olması nedeniyle çalışma; Tıp Fakültesi, Mühendislik Fakültesi, Beden Eğitimi ve Spor Yüksekokulu (BESYO), íktisadi ve İdari Bilimler Fakültesi (iïBF), Ilahiyat Fakültesi, Eğitim Bilimleri Fakültesi ve Fen Edebiyat Fakültesi olmak üzere yedi fakülteden 490 kadın ve erkek öğrenci ile gerçekleştirilmiştir. Uygulama aşamasında haftanın belirlenen iki gününde, her fakülte ayrı zamanlarda iki kez ziyaret edilmiştir. Ziyaret günlerinde fakültede bulunan sınıflarda ders sonrasında öğrencilerle görüşülmüştür. Araştırmanın amacı açıklanarak, araştırmaya katılmayı kabul eden öğrencilere anket formları zarf içerisinde verilmiş ve uygulamadan sonra kapalı bir şekilde zarflar geri alınmıştır. Veriler, literatür doğrultusunda araştırmacılar tarafından özgün olarak hazırlanmış soruları ve ifadeleri içeren anket formu ile toplanmıştır. Anket formunun ilk bölümünde öğrencilerin yaş, cinsiyet, fakülte, sınıf ve cinsellik konusunda bilgi alma durumları ve bilgi kaynakları ile ilgili tanımlayıcı bilgileri yer almıştır. İkinci kısmında ise literatürdeki kaynaklar ve kültürel normlar doğrultusunda araştırmacılar tarafından hazırlanmış cinsellikle ilgili 25 mit yer almaktadır. Mitlerle ilgili ifadelerin geçerlilik güvenirliği yapılmamıştır. Çalışma için Çukurova Üniversitesi Girişimsel Olmayan Klinik Araştırmalar Etik Kurulundan izin alınmıştır (50243401/2020-5). Elde edilen veriler SPSS 21.0 (Statistical Programme for Social Science for Windows) paket programında analiz edilmiştir. Tanımlayıcı değişkenlerin ve cinsel mitlerin dağılımlarını belirlemede yüzdelik, aritmetik ortalama ve standart sapma; tanımlayıcı değişkenler ile cinsel mitlerin karşılaştııımasında ise Ki-kare testi kullanılmıştır. İstatistiksel anlamlılık, $\quad p<0.05$ düzeyinde değerlendirilmiştir.

Çalışmanın yöntemsel bazı sınırlıııları bulunmaktadır. Öncelikle örneklem, çalışmanın yapıldığı üniversitenin tüm birimlerini temsil etmemektedir. Bir diğer sınırlılık örneklem büyüklüğü ile ilişkilidir. Katılımın beklenenden düşük olması nedeniyle belirlenen örneklem büyüklüğüne ulaşılamamıştır. Bu bakımdan çalışma bulgularının evreni temsil etme gücü zayıftır.

\section{Bulgular}

Öğrencilerin yaş ortalaması $21.44 \pm 1.89$ 'dur ve $\% 56.7$ ' si erkektir. Hem kadın hem de erkek öğrencilerin yaklaşık üçte biri ikinci sınıf öğrencisidir. Demografik özellikler bakımından kadın ve erkek öğrenciler arasında anlamlı bir fark yoktur. Fakültelerden en fazla katılım mühendislik fakültesinden olurken, en az ilahiyat fakültesinden olmuştur. Öğrencilerin \%71.2'si cinsellik konusunda bilgi sahibi olduğunu belirtmiştir. Bu konuda bilgi sahibi olduğunu belirten erkeklerin oranı kadınlardan daha yüksektir. Kadınlarda bilgi 
edinme kaynağı olarak "arkadaş" öne çıkarken (\%52.4), erkeklerin bilgi kaynağında daha çok interneti tercih ettikleri görülmüştür (\%60.8). Sağlık personelinden bilgi alma düzeyi \%27.8 'dir (Tablo 1).

Tablo 1. Katılımcıların tanıtıcı özellikleri

\begin{tabular}{|c|c|c|c|c|c|c|}
\hline \multirow[b]{2}{*}{ Özellikler } & \multicolumn{2}{|l|}{ Kadın } & \multicolumn{2}{|l|}{ Erkek } & \multicolumn{2}{|l|}{ Toplam } \\
\hline & $n(212)$ & $\%$ & $n(278)$ & $\%$ & $n(490)$ & $\%$ \\
\hline \multicolumn{7}{|l|}{ Fakülteler } \\
\hline Mühendislik & 65 & 30.7 & 133 & 47.8 & 198 & 40.4 \\
\hline Tıр & 24 & 11.3 & 34 & 12.2 & 58 & 11.8 \\
\hline Beden Eğitimi ve Spor YO. & 17 & 8.0 & 31 & 11.2 & 48 & 9.8 \\
\hline İktisadi İdari Bilimler & 26 & 12.3 & 28 & 10.1 & 54 & 11.0 \\
\hline Ilahiyat & 7 & 3.3 & 8 & 2.9 & 15 & 3.1 \\
\hline Eğitim Bilimleri & 60 & 28.3 & 29 & 10.4 & 89 & 18.2 \\
\hline Fen -Edebiyat & 13 & 6.1 & 15 & 5.4 & 28 & 5.7 \\
\hline \multicolumn{7}{|l|}{ Sinif } \\
\hline 1. sinıf & 51 & 24.1 & 45 & 16.2 & 96 & 19.6 \\
\hline 2. sinif & 75 & 35.4 & 106 & 38.1 & 181 & 36.9 \\
\hline 3. sinıf & 62 & 29.2 & 84 & 30.2 & 146 & 29.8 \\
\hline 4. $\sin I f$ & 24 & 11.3 & 43 & 15.5 & 67 & 13.7 \\
\hline \multicolumn{7}{|l|}{ Yaş } \\
\hline $18-20$ & 80 & 37.7 & 70 & 25.2 & 150 & 30.6 \\
\hline $21-23$ & 116 & 54.7 & 169 & 60.8 & 285 & 58.2 \\
\hline 24 ve üzeri & 16 & 7.6 & 39 & 14.0 & 55 & 11.2 \\
\hline $\begin{array}{l}\text { Cinsellik konusunda bilgi sahibi } \\
\text { olma durumu }\end{array}$ & & & & & & \\
\hline Evet & 146 & 68.9 & 203 & 73 & 349 & 71.2 \\
\hline Hayır & 66 & 31.1 & 75 & 27 & 141 & 28.8 \\
\hline \multicolumn{7}{|l|}{ Cinsellik konusunda bilgi kaynakları } \\
\hline \multicolumn{7}{|l|}{ Aile } \\
\hline Arkadaş & 86 & 40.6 & 88 & 31.7 & 174 & 35.5 \\
\hline Internet & 111 & 52.4 & 145 & 52.5 & 256 & 52.2 \\
\hline Kitap & 90 & 42.5 & 169 & 60.8 & 259 & 52.9 \\
\hline \multirow[t]{2}{*}{ Sağlık personeli } & 91 & 42.9 & 131 & 47.1 & 222 & 45.3 \\
\hline & 53 & 25 & 83 & 29.9 & 136 & 27.8 \\
\hline
\end{tabular}

Kadınların en az \%47.2'si mitleri doğru bulduklarını ifade ederken, erkeklerde bu oranın \%53.2 olduğu görülmüştür. Bu oranlar her iki öğrenciden birisinin en az bir mite inandığını ifade etmektedir. Kadınların ve erkeklerin en çok katıldıkları mit "Erkekler cinsel eyleme hemen hazır ve isteklidir, bir erkek sekse hayır diyemez"dir. Kadınların en çok katılmadıkları mit "Cinsellik penisin vajinaya girmesinden ibarettir." iken, erkeklerinki "Kadınların cinsel ilişkiyi başlatması ahlaksızlıktır" mitidir.

Mitleri onaylama durumları ile cinsiyetler arası karşılaştırmalar Tablo 2'de yer almaktadır (Mitlerin tümü için içerik bölümüne bakınız). Cinsiyetler arası farkın karşılaştırılmasında altı mitin gruplar arasında anlamlı bir farklılık gösterdiği belirlenmiştir. Bu mitlerden "Cinsel zevk için cinsel birleşme önemlidir", "Erkekliğin, cinsel performansın ve cinsel gücün göstergesi sık sık cinsel ilişkide bulunmaktır", "Dokunma, okşama, öpüşme vb. tüm fiziksel yakınlaşmalar cinsel birleşme ile sonuçlanmalıdır" ve "Cinsellik üzerine konuşulmaması cinselliliğin doğal bir şekilde gerçekleştiğinin göstergesidir" de erkekler kadınlardan yüksek oranda katılıyorum ifadesini belirtirken, yine erkekler kadınlardan da yüksek oranda "Mastürbasyon pis ve zararlıdır" ve "Kadınların cinsel ilişkiyi başlatması ahlaksızlıktır" mitlerine katılmadıklarını ifade etmişlerdir. 
Tablo 2: Kadın ve erkek öğrencilerin cinsel mitleri onaylama düzeylerinin karşılaştırılması

\begin{tabular}{|c|c|c|c|c|c|c|c|c|c|c|c|c|c|c|}
\hline \multirow{3}{*}{$\begin{array}{l}\text { Cinsel } \\
\text { Mitler }\end{array}$} & \multicolumn{4}{|c|}{ KADIN } & \multicolumn{4}{|c|}{ ERKEK } & \multicolumn{4}{|c|}{ TOPLAM } & \multirow{3}{*}{$\chi^{2}$} & \multirow{3}{*}{$\mathbf{p}$} \\
\hline & \multicolumn{2}{|c|}{ Katılıyorum } & \multicolumn{2}{|c|}{ Katılmıyorum } & \multicolumn{2}{|c|}{ Katılıyorum } & \multicolumn{2}{|c|}{ Katılmıyorum } & \multicolumn{2}{|c|}{ Katılıyorum } & \multicolumn{2}{|c|}{ Katılmıyorum } & & \\
\hline & $n$ & $\%$ & $n$ & $\%$ & $\mathrm{n}$ & $\%$ & $n$ & $\%$ & $\mathrm{n}$ & $\%$ & $\mathbf{n}$ & $\%$ & & \\
\hline міт 1 & 191 & 90,1 & 21 & 9,9 & 238 & 85,6 & 40 & 14,4 & 492 & 87,6 & 61 & 12,4 & 2,218 & 0,136 \\
\hline міт 2 & 162 & 76,4 & 50 & 23,6 & 232 & 83,2 & 46 & 16,5 & 394 & 80,4 & 96 & 19,6 & 3,782 & 0,052 \\
\hline міт 3 & 200 & 94,3 & 12 & 5,7 & 266 & 95,7 & 12 & 4,3 & 466 & 95,1 & 24 & 4,9 & 0,466 & 0,495 \\
\hline міт 4 & 147 & 69,3 & 65 & 30,7 & 213 & 76,6 & 65 & 23,4 & 360 & 73,5 & 130 & 26,5 & 3,270 & 0,071 \\
\hline міт 5 & 150 & 70,8 & 62 & 23,4 & 202 & 72,7 & 76 & 27,3 & 352 & 71,8 & 138 & 28,2 & 0,216 & 0,642 \\
\hline міт 6 & 166 & 78,3 & 46 & 21,7 & 251 & 90,3 & 27 & 9,7 & 417 & 85,1 & 73 & 14,9 & 13,629 & 0,000 \\
\hline міт 7 & 165 & 77,8 & 47 & 22,2 & 210 & 75,5 & 68 & 24,5 & 375 & 76,5 & 115 & 23,5 & 0,351 & 0,553 \\
\hline міт 8 & 162 & 76,6 & 50 & 23,6 & 201 & 72,3 & 77 & 27,7 & 363 & 74,1 & 127 & 25,9 & 1,060 & 0,303 \\
\hline міт 9 & 181 & 85,4 & 31 & 14,6 & 251 & 90,3 & 27 & 9,7 & 432 & 88,2 & 58 & 11,8 & 2,779 & 0,096 \\
\hline міт 10 & 141 & 66,5 & 71 & 33,5 & 187 & 67,3 & 91 & 32,7 & 328 & 66,9 & 162 & 33,1 & 0,031 & 0,860 \\
\hline міт 11 & 175 & 82,5 & 37 & 17,5 & 236 & 84,9 & 42 & 15,1 & 411 & 83,9 & 79 & 16,1 & 0,489 & 0,484 \\
\hline міт 12 & 100 & 47,2 & 112 & 52,8 & 148 & 53,2 & 130 & 46,8 & 248 & 50,6 & 242 & 49,4 & 1,772 & 0,183 \\
\hline міт 13 & 143 & 67,5 & 69 & 32,5 & 221 & 79,5 & 57 & 20,5 & 364 & 74,6 & 126 & 25,7 & 9,133 & 0,003 \\
\hline міт 14 & 185 & 87,3 & 27 & 12,7 & 257 & 92,4 & 21 & 7,6 & 442 & 90,2 & 48 & 9,8 & 3,655 & 0,056 \\
\hline міт 15 & 147 & 69,3 & 65 & 30,7 & 214 & 77 & 64 & 23 & 361 & 73,7 & 129 & 26,3 & 3,619 & 0,057 \\
\hline міт 16 & 184 & 86,8 & 28 & 13,2 & 233 & 83,8 & 45 & 16,2 & 417 & 85,1 & 73 & 14,9 & 0,842 & 0,359 \\
\hline міт 17 & 190 & 89,6 & 22 & 10,4 & 251 & 90,3 & 27 & 9,7 & 441 & 90 & 49 & 10 & 0,059 & 0,808 \\
\hline міт 18 & 136 & 64,2 & 76 & 35,8 & 206 & 74,1 & 72 & 25,9 & 342 & 69,8 & 148 & 30,2 & 5,648 & 0,017 \\
\hline міт 19 & 183 & 86,3 & 29 & 13,7 & 218 & 78,4 & 60 & 21,6 & 401 & 81,8 & 89 & 18,2 & 5,055 & 0,025 \\
\hline міт 20 & 144 & 67,9 & 68 & 32,1 & 198 & 71,2 & 80 & 28,8 & 342 & 69,8 & 148 & 30,2 & 0,621 & 0,431 \\
\hline міт 21 & 116 & 54,7 & 96 & 45,3 & 131 & 47,1 & 147 & 52,9 & 247 & 50,4 & 243 & 49,6 & 2,775 & 0,096 \\
\hline міт 22 & 139 & 65,6 & 73 & 34,4 & 150 & 54 & 128 & 46 & 289 & 59 & 201 & 41 & 6,700 & 0,010 \\
\hline міт 23 & 161 & 75,9 & 51 & 24,1 & 226 & 81,3 & 52 & 18,7 & 387 & 79 & 103 & 21 & 2,075 & 0,150 \\
\hline міт 24 & 102 & 48,1 & 110 & 51,9 & 104 & 37,4 & 174 & 62,6 & 206 & 42 & 284 & 58 & 5,655 & 0,017 \\
\hline міт 25 & 106 & 50 & 106 & 50 & 138 & 49,6 & 140 & 50,4 & 244 & 498 & 246 & 50,2 & 0,060 & 0,937 \\
\hline
\end{tabular}

Mitler ile yaş, fakülte ve sınıf düzeyleri arasındaki karşılaştırmalarda mit 1, 3, 8, 9, 11, 17, 19, 23 arasında istatistiksel olarak anlamlı bir ilişki yoktur. Ancak bu değişkenlerin diğer mitler ile arasındaki ilişki istatistiksel olarak anlamlıdır. "Penis boyu cinsellik gücü ve zevk ile doğru orantılıdır" mitini erkeklerin onaylama düzeyi sınıf düzeyi arttıkça azalmaktadır $\left(\chi^{2}=4.854, p=0.028\right)$. "ilişkiye giren çift içgüdüsel olarak karşısındakinin ne istediğini bilir" miti ile yaş, sınıf düzeyi ve bölüm değişkenleri arasındaki fark anlamlıdır. Erkeklerin yaşı $\left(\chi^{2}=6.885, p=0.032\right)$ ve sınıf düzeyi $\left(\chi^{2}=10.942, p=0.001\right)$ arttıkça bu mite inanma düzeyleri azalmaktadır. Bölümler arasındaki farkta ise eğitim bilimlerindeki erkek öğrenciler diğer bölümlere göre bu mite daha fazla inanmaktadır $\left(\chi^{2}=5.220, p=0,022\right)$. "Seksi her zaman erkek başlatır" miti ile yaş ve sınıf düzeyi arasında anlamlı bir ilişki bulunmamıştır. Ancak bölümler arasındaki fark anlamlı olup, tıp fakültesindeki erkek öğrencilerin bu mite daha fazla inandığı belirlenmiştir $\left(\chi^{2}=4.063, p=0.037\right)$. "Cinsel zevk için cinsel 
birleşme önemlidir" miti ile yaş arasında anlamlı bir ilişki bulunmamıştır. Ancak bölüm ve sınıf düzeyi arasındaki ilişki anlamlıdır. Tıp fakültesinde okuyan erkek öğrenciler diğer bölümlere oranla bu mite daha fazla inanmaktadır $\left(\chi^{2}=4.4063, p=0.044\right)$. Sınıf düzeyi ilerledikçe mite inama düzeyleri azalmaktadır $\left(\chi^{2}=6.370, p=0.012\right)$. "Cinsel ilişki sırasında karşılıklı mastürbasyon yanlıştır" miti ile yalnızca bölümler arasında anlamlı bir ilişki vardır. Illahiyat fakültesindeki kadın öğrenciler bu mite daha fazla inanmaktadır $\left(\chi^{2}=4.773 p=0.029\right)$. "Cinsel ilişki ancak çiftin aynı anda orgazm olmasıyla güzel ve iyidir" mitine ise eğitim fakültesi kadın öğrencileri daha fazla inanmaktadır $\left(\chi^{2}=4.895, p=0.027\right)$. "Dokunma, okşama, öpüşme vb. tüm fiziksel yakınlaşmalar cinsel birleşme ile sonuçlanmalıdır" mitine ise eğitim fakültesi erkek öğrencilerinin daha yüksek oranda inandıkları belirlenmiştir $\left(\chi^{2}=8.388, p=0.004\right)$. "Cinsellik doğaldır, öğrenilemez" ile yaş ve sınıf düzeyi arasında anlamlı bir ilişki görülmezken, ilahiyat fakültesindeki kadın öğrencilerin bu mite inanma düzeylerinin diğer bölümlere göre daha yüksek olduğu belirlenmiştir $\left(\chi^{2}=4.773\right.$, $p=0.029$ ).

"Cinsellikte performans önemlidir" ve "Cinsellikte erkek yöneticidir, her şeyi bilir" mitlerine erkeklerin yaşı ilerledikçe inanma düzeyleri azalmaktadır $(p<0.05)$. "Cinsellik penisin vajinaya girmesinden ibarettir" mitinde erkeklerin inanma oranları sınıf düzeyi arttıkça artarken $\left(\chi^{2}=4.245, p=0.039\right)$, "Erkekliğin, cinsel performansın ve cinsel gücün göstergesi sık sık cinsel ilişkide bulunmaktır" mitinde inanma oranı sınıf düzeyi arttıkça azalmaktadır $\left(\chi^{2}=6.242, p=0.012\right)$. "Cinsellikte kesin, evrensel doğrular vardır" miti ile yaş ve bölümler arasında anlamlı bir ilişki varken sınıf düzeyleri arasında anlamlı bir ilişki bulunmamıştır. Kadınların yaşı ilerledikçe mite inanma düzeyleri azalırken $\left(\chi^{2}=6.175, p=0.05\right)$, tıp fakültesi ve iiBF kadın öğrencileri diğer bölümlere göre bu mite daha fazla inanmaktadır $\left(\chi^{2}=4.905 p=0.027\right)$. Yaş ilerledikçe "Cinsel fanteziler kurmak yanlıştır" mitine erkeklerin inanma düzeyleri anlamlı olarak azalmaktadır $\left(\chi^{2}=5.969, p=0.05\right)$. Mühendislik fakültesindeki kadın öğrencilerin bu mite inanma düzeyleri ise diğer bölümlere göre daha yüksektir ( $\chi^{2}=6.494, p=0.011$ ). "Mastürbasyon pis ve zararlıdır" ile sınıf düzeyi ve bölümler arasında anlamlı bir ilişki yoktur. Ancak yaş ilerledikçe erkek öğrencilerin mite inanma düzeyleri anlamlı düzeyde azalmaktadır $\left(\chi^{2}=6.066, p=0.048\right)$.

"Kadınların cinsel ilişkiyi başlatması ahlaksızlıktır" miti ile yaş ve sınıf düzeyi arasında anlamalı bir ilişkili bulunmamıştır. Ancak BESYO'daki erkek öğrencilerin bu mite inanma düzeyleri diğer bölümlerden daha düşüktür $\left(X^{2}=6.831, p=0.009\right)$. "kadınlar sadece penis hareketleri ile orgazm olmalıdırlar" mitine erkek öğrencilerin yaş ilerledikçe inanma düzeyi azalırken $\left(\chi^{2}=13.202, p=0.001\right)$ kadınların inanma düzeyi artmaktadır $\left(\chi^{2}=8.907, p=0.012\right)$. Illahiyat fakültesi kadın öğrencilerin bu mite inanma düzeyleri diğer bölümlere göre daha yüksektir $\left(\chi^{2}=6.563, p=0.01\right)$.

Cinsellik konusunda en fazla bilgi sahibi olduğunu belirten öğrenciler, mühendislik fakültesi öğrencileridir( \%42.4). Bu fakülteyi sırasıyla eğitim fakültesi, tıp fakültesi, iiBF, BESYO ve fen edebiyat fakültesi öğrencileri takip etmektedir. En az bilgi sahibi olduğu belirlenen ise ilahiyat fakültesi öğrencileridir (\%2.6). Daha önceden cinsellik konusunda bilgi sahibi olma durumu ile "Seksi her zaman erkek başlatır"(mit 5), "dokunma, okşama, öpüşme vb. tüm fiziksel yakınlaşmalar cinsel birleşme ile sonuçlanmalıdır" (mit 18) ve "kadınların cinsel ilişkiyi başlatması ahlaksızlıktır" (mit 24) mitleri arasında anlamlı bir fark olduğu belirlenmiştir. Bu ilişkide daha önceden cinsellik konusunda bilgi sahibi olduğunu belirtenler "seksi her zaman erkek başlatır" ve "Dokunma, okşama, öpüşme vb. tüm fiziksel yakınlaşmalar cinsel birleşme ile sonuçlanmalıdır" mitlerine daha yüksek oranda katııırken, "kadınların cinsel ilişkiyi başlatması ahlaksızlıktır" mitine katılmadıklarını ifade etmişlerdir.

Cinsiyet farklılığı dikkate alınarak bilgi düzeyi ile mitlerin ilişkisi üzerine yapılan ileri analizlerde kadın ve erkek katılımcıların farklı mitlerde farklı görüşlerinin olduğu belirlenmiştir. Kadın katılımcılar "erkekler cinsel eyleme hemen hazır ve isteklidir, bir erkek sekse hayır diyemez", "ilişkiye giren çift içgüdüsel olarak 
karşısındakinin ne istediğini bilir", "seksi her zaman erkek başlatır" ve "cinsellikte performans önemlidir" mitlerine daha yüksek oranda katıldıklarını ifade ederken, "Kadınların cinsel ilişkiyi başlatması ahlaksızıktır" ve "Kadınlar sadece penis hareketleri ile orgazm olmalıdırlar" mitlerine erkeklerden daha yüksek oranda katılmadıklarını ifade etmiştir ve bilgi düzeyi ile aralarında anlamlı ilişki olduğu belirlenmiştir. Erkeklerde ise mitler ve cinsellik konusunda anlamlı ilişki içerisinde olan mit sayısı kadınlardan daha az sayıdadır. "erkekler kadınlara nasıl zevk verileceğini bilir", "Dokunma, okşama, öpüşme vb. tüm fiziksel yakınlaşmalar cinsel birleşme ile sonuçlanmalıdır" ve "Cinsellik üzerine konuşulmaması cinselliğin doğal bir şekilde gerçekleştiğinin göstergesidir" mitlerine cinsellik konusunda bilgi sahibi olduğunu belirtenlerin daha yüksek oranda katıldıkları belirlenmiştir.

Cinsellik konusunda bilgiye kaynakları ile bazı mitler arasında anlamlı bir ilişki olduğu belirlenmiştir. "Erkekler cinsel eyleme hemen hazır ve isteklidir, bir erkek sekse hayır diyemez" mitine, cinsellik konusunda bilgi kaynağı olarak arkadaşını seçenlerin inanma düzeyleri anlamlı düzeyde yüksektir $\left(\chi^{2}=5.387, p=0.020\right)$. Bilgiye, internetten ulaşanların ise "cinsellik penisin vajinaya girmesinden ibarettir", "eğer iki insan birbirlerini seviyorlarsa cinsel ilişkiden zevk almasını da bilirler" ve "dokunma, okşama, öpüşme vb. tüm fiziksel yakınlaşmalar cinsel birleşme ile sonuçlanmalıdır" mitlerine inama düzeyleri anlamlı olarak daha yüksektir $(p<0.01)$. Kaynak olarak kitap, dergi gazeteyi tercih etmiş olanların ise "Kadınların cinsel ilişkiyi başlatması ahlaksızlıktır" mitine inanma düzeyleri daha düşükken $\left(\chi^{2}=4.339, p=0.037\right)$, "ilişkiye giren çift içgüdüsel olarak karşısındakinin ne istediğini bilir" mitine inanma düzeyleri daha yüksektir $\left(\chi^{2}=6.188\right.$, $p=0.013$ ). Bilgiyi bir sağlık personelinden edindiğini belirtenlerin "Cinsel zevk için cinsel birleşme önemlidir", "Erkeğin penisinde sertleşmenin kaybı eşini çekici bulmadığı anlamına gelir", "Cinsel ilişki ancak çiftin aynı anda orgazm olmasıyla güzel ve iyidir" ve "Cinsellikte erkek yöneticidir, her şeyi bilir" mitlerine inanma düzeyleri anlamlı olarak daha yüksektir $(p<0.001)$.

\section{Tartışma}

Toplumlarda yaygın olarak inanılan cinsel mitler, üreme sağlığı başta olmak üzere, ruhsal ve sosyal olarak da bireylerin sağılıkı olma halini etkiyecektir. Bu mitlerin bir başkası tarafından onaylanıyor olması ve bilginin aktarımında kişisel kaynakların ön plana çıkması cinsel işlev bozukluğuna sebep olacağı gibi, duygusal partner ilişkilerinin de bu sebeple etkilenebileceği yapılan çalışmalarda pek çok kez ifade edilmiştir. ${ }^{1,25,15,17}$

Sağlık alanında eğitim gören öğrencilerin cinsellik konusunda bilgiye daha rahat ulaşmaları beklenirken çalışmamızda en fazla bilgi sahibi olduğunu belirtenlerin mühendislik fakültesi öğrencileri olduğu görülmüştür. Bu sonucun çıkmasında en etkili faktörün bilgi kaynakları olduğu düşünülmektedir. Çalışmamızda kadın öğrencilerin çoğunlukla arkadaşlarını, erkek öğrencilerin ise interneti kaynak olarak kullandıkları belirlenmiştir. Kukulu ve ark.'nın fakülteler arası karşılaştırılmasını yaptıkları çalışmasında da benzer bir bulguya dikkat çekilmiştir. ${ }^{25}$ Mitlerin kavramsal tanımından yola çıktığımızda yaşanılan toplum, kültür ve değerlerin bu yönelimi etkilediğini de söyleyebilmek mümkündür. Türkiye'de yapılmış diğer cinsiyete özel çalışmalarda da benzer sonuçlara ulaşılmıştır. ${ }^{24-32,34-35}$ Bu sonuç erkek ya da kadın olmanın kaynaklara ulaşmak ve cinselliğin konuşabilirliği bakımından belirgin bir fark yaratmadığını düşündürmektedir.

Çalışmada her fakülteyi temsil eden bir örnekleme ulaşmak hedeflenmiştir. Bu amaç doğrultusunda en az temsiliyete sahip olan ilahiyat fakültesidir. Cinsel mitler ve üniversite öğrencilerini konu olan çalışmalarda genel olarak cinsiyetler arası karşılaştırmalar öne çıkmakla birlikte Kukulu ve ark. fakülteler arası sonuçları temel bilim alanları çerçevesinde incelemiştir. ${ }^{25}$ Sağlık, sosyal ve fen bilim alanları arasında istatistiksel olarak anlamlı bir fark belirtmektedir. Farklılıklar "kadın bekaretinin evlilikte erkek cinsel memnuniyeti için önemli", "mastürbasyon zararlı", "mastürbasyon günahtır", "penis temizliği için sünnet gereklidir" ve "insanların kıyafeti ve davranışlarının cinselliği teşvik ettiği mitleri ile ilgilidir. Bununla birlikte, bu mitleri 
kabul eden veya reddeden öğrencilerin yüzdesi sosyal bilimler, fizik bilimleri ve sağlık bilimleri bölümlerinde oldukça benzer olduğunu belirtmiştir. Çalışmamızda ise mitler inanma durumu ile fakülteler arası farkın karşılaştırımasında "erkeklerin cinsel dürtüleri kadınlara göre daha fazladır", "erkekler cinsel eyleme hemen hazır ve isteklidir, bir erkek sekse hayır diyemez", "erkeğin penisinde sertleşmenin kaybı eşini çekici bulmadığı anlamına gelir", erkekler kadınlara nasıl zevk verileceğini bilir", "cinsellikte başarılı olmak çok önemlidir", "sevişme sırasında konuşulmaz", "eğer iki insan birbirlerini seviyorlarsa cinsel ilişkiden zevk almasını da bilirler", "cinsellik üzerine konuşulmaması cinselliğin doğal bir şekilde gerçekleştiğinin göstergesidir" ve "sertleşmiş ve büyük bir penis iyi bir cinsel ilişki için gereklidir" mitleri arasında anlamlı bir fark olmadığı görülmüştür. Bilim alanları altında birleştirilen fakültelerin arasında da cinsel mitlere inanma düzeyleri bakımından anlamlı bir fark olmadığı belirlenmiştir.

Özsoy ve Bulut hemşirelik öğrencileriyle yaptıkları çalışmada cinsel sağılı bilgisi dersi öncesi ve sonrasında anlamlı düzeyde fark belirlemişlerdir. ${ }^{29}$ Benzer şekilde Aker ve Böke çalışmasında verilen eğitimle cinsel mitleri onaylama oranın ciddi düzeydi azaldığı ifade edilmiştir. Ancak her iki çalışma da tamamen değiştiğini ifade etmemiştir. ${ }^{37}$ Eğitim öncesine göre inanılan mit sayısının eğitim sonrasında azaldığını ifade eden çalışma bulguları, eğitimle belirli düşünce kalıplarına ulaşmış bireylerin fikirlerinde keskin değişiklikler olmadığı yönünde yorumlanabilir. ${ }^{29}$ bu sebeple cinsel eğitim temelde ailede başlanması önerilir. ${ }^{38}$ Ancak cinsel tutum ve davranışlar hakkındaki bilgilere erişimi kısıtlayabilen geleneksel değerler, geleneksel toplumlardaki aileler ve gençler arasında cinsel sorunlara ilişkin tartışmaların önündeki başlıca engeller olabilir. ${ }^{39}$ Konu olarak bir tabudur ve okullarda cinsellik konusunda verilen eğitim minimum düzeydedir. Ayrıca, ebeveynler ve sağlık profesyonelleri cinselliği tartışmak veya cinsellik bilgisi sağlamak konusunda isteksiz olabilirler. ${ }^{39}$ bu bakımdan cinsellik konusunda verilecek eğitimin, formal eğitimin her aşamasında bireyin yaşına özel eğitimin bir parçası olmakla kalmayıp, yaşam boyu devam eden bir işleyişte olmalıdır.

Kadın ve erkek öğrencilerin en çok katıldıklarını mit "erkekler cinsel eyleme hemen hazır ve isteklidir, bir erkek sekse hayır diyemez" mitidir. Bu mit Türkiye'de yapılmış cinsiyete özel ya da cinsiyet karşılaştırmalı çalışmalarda da benzer şekilde yaygın olarak inanılan mittir. ${ }^{25,27,30,34}$ Çalışmamızda öğrencilerin \%95.1'i tarafından onaylanan bu mit, benzer şekilde, Ejder Apay ve ark.'nın çalışmasında \%66.2, Aygin ve ark.'nın çalışmasında \%73.9, Bostancı ve ark.'nın çalışmasında ise \%58 ile en çok onaylanan mittir. ${ }^{27,30,36}$ Torun ve ark.'nın çalışmasında \%73.1 ile ikinci en çok onaylanan, Kukulu ve ark.'nın çalışmasında ise \%27.8'lik oranı ile dördüncü en çok onaylanan mittir. ${ }^{25}$ Ancak çalışma bulgularımızın diğer çalışmalardan daha yüksek oranda olduğu gözlenmiştir. Bu sonucun, üniversitenin bulunduğu il ve çevre illerin gelenekselliğin daha yoğun görüldüğü yerler olması ve bu bölgelerde yaşayan gençlerin yoğunlukla tercih ettiği bir üniversite olmasından kaynaklanabileceği düşünülmektedir. Erkekte performans kaygısına sebep olabilecek bu mit, geleneksel olarak aktif olma, sorumluluk alma, cinsel ilişkiyi başlatma ve sürdürme gibi psikolojik yükleri ile erkeklerde cinsel ilişkinin bir görev olarak algılanmasına sebep olabilecektir. Başarısızlığa ihtimal bırakmayan bu mit erkekte kaygı yaratırken, kadında partnerin kendisini çekici bulmaması gibi bir kaygıyı da beraberinde getirecek ve çiftlerin her ikisini de etkileyebilecektir.

Kadınlar en az oranda "cinsellik penisin vajinaya girmesinden ibarettir" mitini onayladıklarını ifade ederken $(\% 47,2)$, erkeklerde en az onaylanan "cinsel fanteziler kurmak yanlıştır" mitidir $(\% 47,1)$. Cinsiyet ayrımı olmadan bakıldığında ise "kadınların cinsel ilişkiyi başlatması ahlaksızlıktır" en az onaylanan mittir (\%42). İlginç olan kadınların bu miti onaylama oranlarının erkeklerden daha yüksek olmasıdır (Tablo 2). Kukulu ve ark.'nın çalışmasında "cinsel ilişkiyi kadının başlatması ahlaksızlıktır" mitini onaylama düzeyinin oldukça düşük olduğu görülmüştür (\%7.2). ${ }^{25}$ Benzer şekilde iki farklı ülkede öğrencilerin mitlere yaklaşımını değerlendiren Ejder Apay ve ark.'nın bulgularında da en az onaylanan mitler arasındadır. ${ }^{27}$ Aygin ve ark.'nın çalışmasında bu miti onaylama oranı \%10.2'dir. ${ }^{30}$ Aker ve Böke'nin çalışmasında ise bu mit katılımcıların hiç 
onaylamadığı bir mit olarak belirtilmiştir. ${ }^{37}$ Benzer araştırmalar incelendiğinde, bireylerin bu mite “tamamen doğru/katılıyorum” deme oranları, \%4-40 arasında değiştiği görülmüştür. ${ }^{19,25,29,31,38,40,41}$ Bireylerin onaylama oranı diğer çalışma bulgularından yüksek olmakla birlikte benzer şekilde en az düzeyde onaylanan mittir. Bu sonucun en çok onaylanan mitlerdekine benzer bir sebeple ilişkili olduğu düşünülmektedir.

Kilci'nin evlilik hazırladığındaki çiftlerin cinsel mitlere inanma durumlarını inceledikleri çalışmada en fazla inanılan mit, "eğer iki insan birbirlerini seviyorlarsa cinsel ilişkiden zevk almasını da bilirler" $(\% 83,9)$ mitidir. ${ }^{40}$ Çalışmamızda ise bu oran \%90'dır. Farklı gruplarla yapılan birçok araştırmada da bireylerin en çok inandığı mitler arasında yer aldığı ve inanma oranlarının \%67-86 arasında değiştiği görülmüştür. ${ }^{13,24,25,27,30,40,41}$ Sevgi, cinsel birliktelik için iyi bir zemin olmakla birlikte yeterli değildir. ${ }^{40}$ Araştırma sonuçları bu cinsel mite, öğrencilerin yaygın olarak inandığını göstermektedir.

Oldukça yüksek oranlarda onaylanan bir diğer mit "cinsel ilişki ancak çiftin aynı anda orgazm olmasıyla güzel ve iyidir" $(\% 90,2)$ mitidir. Genç ya da yetişkin bireylerle yapılan birçok çalışmada bu mite inanma oranının \%50-93 arasında değiştiği görülmüştür. ${ }^{15,10,24,32,41,30}$ CETAD'ın yeni ve modern bir yanlış inanış olarak ifade ettiği bu mit çiftlerin birlikte orgazm olmaması durumunda eksik duygusu yaşamasına sevk edebilmektedir. ${ }^{40}$ "ilişkiye giren çift içgüdüsel olarak karşısındakinin ne istediğini bilir" mitini katılımcıların $\% 73,5^{\prime} \mathrm{i}$, onayladıklarını belirtmiştir. Bozkurt'un çalışmasında ise bu mite inanma oranı ise kadınlarda \%11, erkeklerde \%3'tür. ${ }^{41}$ Yapılan diğer araştırmalarda bu mite inanma oranının \%61-92 arasında olup, bu çalışma bulgusuna benzer düzeylerdedir. ${ }^{10,15,24,30,32,39,40}$ Bu düşünce, cinsel yaşamın çeşitli aktif çabalarla daha da güzelleşebileceğini ve bu konuda çiftlerin yapabileceği şeyler olduğunu inkâr eden bir varsayımı destekleyebilmektedir. Bu durum çiftlerin sorun yaşandığında kendilerinde bir eksiklik olduğu duygusunu destekler niteliktedir. ${ }^{40}$

"Mastürbasyon pis ve zararlıdır mitini" katılımcıların \%59'u onayladıklarını ifade etmiştir. Kilci'nin çalışmasında bu oran \%14.3, Ejder Apay ve ark.'nın çalışmasında ise \%33.3'dür. ${ }^{27,42}$ Çalışma sonucu diğerlerinden yüksek olmakla birlikte çalışma grubunun benzer olması sebebiyle Ejder Apay ve ark'nın çalışma bulgusuna daha yakındır. "erkeğin penisinde sertleşmenin kaybı eşini çekici bulmadığı anlamına gelir" \%74.1'dir. Ejder Apay ve ark.'nın bulgularında bu mitin onaylama düzeyi çalışmamızdan oldukça düşüktür(\%12.8), Kilci'nin çalışmasında da bu oran \%14.3'tür. ${ }^{27,42}$ Çalışmamızda bu oran hem kadın hem de erkelerde oldukça yüksektir. Bu durum erkeklerin performans kaygısı duygusunu öne çıkarırken, kadınların çekici olmadığı endişesi yaşamasına neden olabilmektedir.

Cinsel Eğitim Tedavi ve Araştırma Derneği'nin (CETAD) 2006 yılında Türkiye genelinde yaptığı çalışmada, özellikle kadın ve erkekler arasındaki farklı beyanların iki önemli tespiti beraberinde getirdiğini belirtmişlerdir. Kadınlar yüksek oranda bilgisizdir ve erkekler yüksek oranda yanlış bilgilidir. Yine aynı çalışma sonuçlarında, seçilen ifadenin sonuçlarına göre cinsel mitlerin yanlışlı̆ının farkında olanların oranı $\% 25^{\prime}$ tir. $^{40}$ Bulgularımızda kadınların en az ve en çok inandıkları mit oranları \%47.2-94.3, erkeklerin ise \%47.1-95.7 arasında değişmektedir. Bu sonuç CETAD'ın yaptığı çalışmanın üzerinden 10 yıldan fazla süre geçmiş olmasına rağmen yaygın olarak mitlere inandıklarına dikkat çekmektedir.

\section{Sonuç ve Öneriler}

Çalışma bulguları hem cinsiyete özel hem de genel sonuçları bakımından, öğrencilerin yüksek düzeyde cinsel mitleri onayladığını ve sağlıklı cinsel yaşam konusunda doğru bilgiden yararlanma oranlarının düşük olduğunu göstermektedir. Doğru kaynakları kullanarak cinsellik hakkında bilgi sahibi olmanın, cinsiyeti sağlıklı bir şekilde deneyimlemenin önemli bir göstergesi olduğu yadsınamaz bir gerçektir. Çocukluk ve ergenlik dönemlerinin psiko-cinsel gelişimi sırasında elde edilen yetersiz veya yanlış bilgiler, cinsellikten kaynaklanan yanlış ve abartılı beklentiler, bireyin yetişkinlik dönemindeki cinsel inanç ve davranışlarına da 
yansıyacaktır. Cinsel disfonksiyonla ilişkilendirilen bu inanışlar partnerlerin cinsel yaşamını olumsuz etkileyecektir. Cinsellik hakkında kulaktan dolma, bilimsel olmayan ve eksik bilgi yerine, profesyonellerin rehberliğinde açık, bilimsel ve anlaşılır cinsel eğitim programları tasarlamak önemlidir. Bu eğitimler her yaş ve eğitim düzeyine uygun, sürdürülebilir nitelikte olmalıdır. Cinsellik eğitim programlarının içeriği hazırlanırken cinsel mitlerle ilgili çalışmaların bulguları dikkate alınmalıdır.

\section{İçerik}

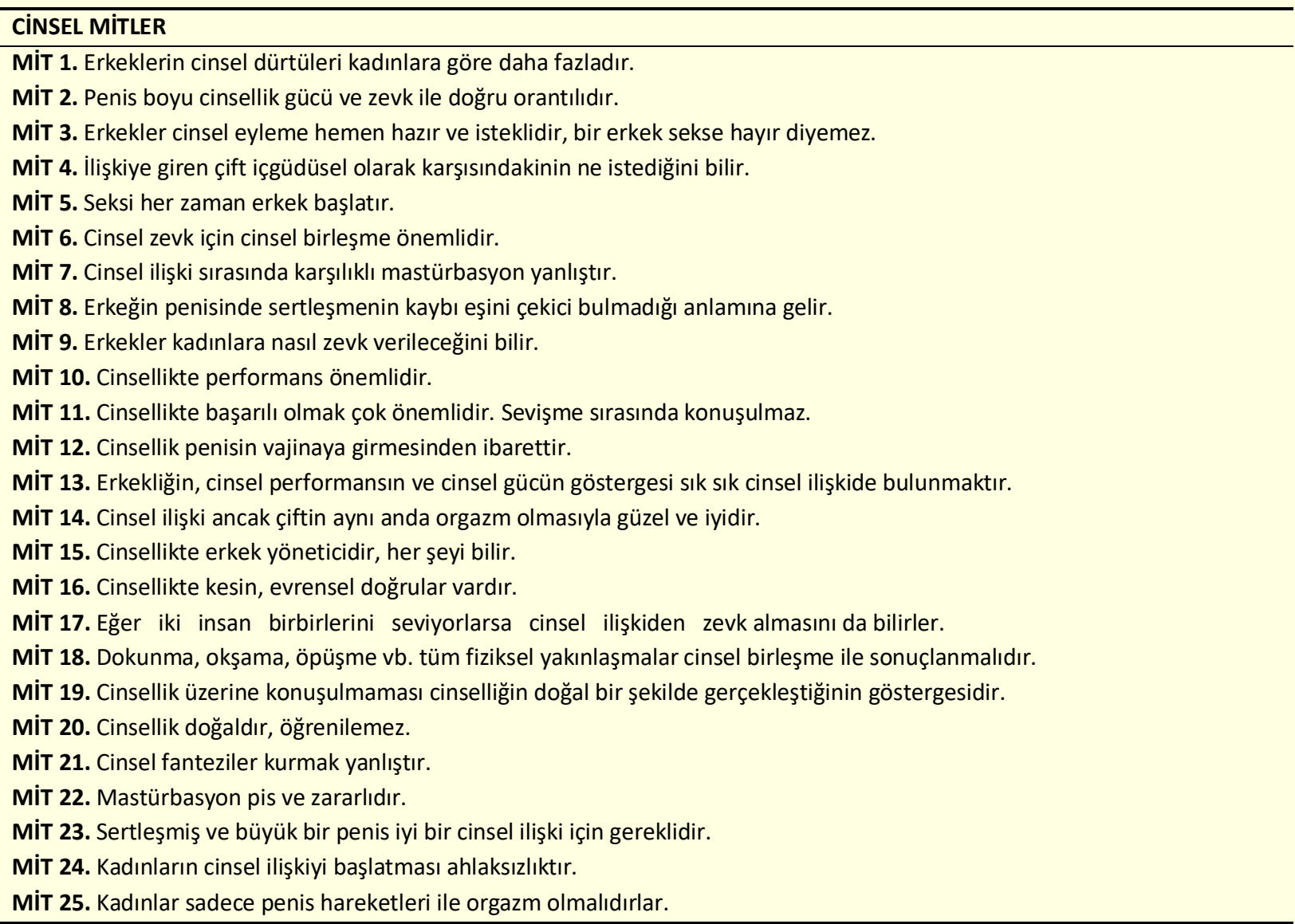

\section{Bilgi}

Yazar çıkar çatışması yaratabilecek maddi destek ve ilişkilerinin olmadığını beyan etmektedir.

\section{Etik Onay}

Çukurova Üniversitesi Tıp Fakültesi Girişimsel Olmayan Klinik Araştırmalar Etik Kurulundan izin alınmıştır (50243401/2020-5).

\section{Kaynaklar}

1. World Health Organisation (WHO), 2017. Sexual health and its linkages to reproductive health: an operational approach. Geneva: WHO. Erişim: https://apps.who.int/iris/bitstream/handle/10665/258738/9789241512886eng.pdf;jsessionid=EA80278CEB5F05A76F3C2C6530DB9D54?sequence $=1$

2. World Association of Sexual Health (WAS), 2013. Working Definitions after WHO Technical Consultation on Sexual Health. Erişim: http://176.32.230.27/worldsexology.org/wp-content/uploads/2013/08/working-definitions-after-who.pdf.

3. Campbell J. The power of myth with Bill Moyers. New York: Anchor Books; 1991.

4. May R. The cry for myth. New York: WW Norton \& Company; 1990.

5. Ryan KM. The relationship between rape myths and sexual scripts: The social construction of rape. Sex Roles 2011;65(11-12): 774-782. 
6. Baker C, De Silva P. The relationship between male sexual dysfunction and belief in Zilbergeld's myths: An empirical investigation. Sex Marital Ther 1988; 3: 229-238.

7. Zilbergeld B. The New Male Sexuality: The truth about men, sex, and pleasure. New York: Batam Books; 1999.

8. Nobre PJ, Pinto-Gouveia J, Gomes FA. Sexual dysfunctional beliefs questionnaire: An instrument to assess sexual dysfunctional beliefs as vulnerability factors to sexual problems. Sex Relationp Ther 2003; 18: 171-204.

9. Brotto $L$, et al. Acculturation and sexual function in Asian women. Arch Sex Behav 2005; 34: 613-26.

10. Torun F, Torun SD, Özaydın AN. Erkeklerde cinsel mitlere inanma oranları ve mitlere inanmayı etkileyen faktörler. Düşünen Adam Psikiyatri ve Nörolojik Bilimler Dergisi 2011; 24(1): 24-31.

11. Yılmaz M, Karataş B. Opinions of student nurses on sexual myths; a phenomenological study. Sex Disabil 2018; 36(3): $277-289$.

12. Özmen HE. Cinsel mitler ve cinsel işlev bozuklukları. Psikiyatri Dünyası 1999; 2: 49-53.

13. Kora K, Kayır A. Cinsel roller ve cinsel mitler. Düşünen Adam Psikiyatri ve Nörolojik Bilimler Dergisi 1996; 9: 55-58.

14. Zilbergeld B. Seksi öğrenmek. Demiriz G, (çeviri editörü). Erkek cinselliği. İstanbul: Bilimsel ve Teknik Yayınları Çeviri Vakfı,1994. pp: 9- 17.

15. Kayır A. Cinsel mitler. Ero cinsel yaşam ansiklopedisi. Milano: AMARE Gruppo, 1996; 2: 26-28.

16. Abdolmanafi $A$, et al. Sexual dysfunctional beliefs questionnaire (SDBQ): Translation and psychometric properties of the Iranian version. J Sex Med 2015; 12 (8): 1820-1827.

17. İncesu C. Cinsel sağıık ve üreme sağlığı alanında ulusal ve yerel medya yoluyla savunuculuk projesi: Cinsel yaşam ve sorunları, bilgilendirme dosyası. Cinsel Eğitim Tedavi ve Araştırma Derneği(CETAD), 2007.

18. Gunes M, ve ark. Prematür ejakülasyon olgularında cinsel mitlere inanma düzeyi. Dicle Tıp Dergisi 2016; 43(2): $319-328$.

19. Ogur $P$, Utkualp N, Aydınoğlu N. Sağlık yüksekokulu öğrencilerinin cinsellikle ilgili inanışları. STED 2016; 1(25): 13-21.

20. Borg C, de Jong PJ, Schultz WW. Vaginismus and dyspareunia: Relationship with general and sex-related moral standards. J Sex Med 2008; 6(1): 223-231.

21. Nobre PJ, Pinto-Gouveia J. Dysfunctional sexual beliefs as vulnerability factors to sexual dysfunction. J Sex Res 2006; 43(1): 6875.

22. T.C. Aile ve Sosyal Politikalar Bakanlığı Aile ve Toplum Hizmetleri Genel Müdürlüğü. Türkiye boşanma nedenleri araştırması 2014. Erişim: https://www.aysedenizoral.av.tr/wp-content/uploads/2017/11/tbna2014_kitap.pdf

23. Türkiye İstatistik Kurumu, Toplumsal cinsiyet istatistikleri (2019), Erişim: https://biruni.tuik.gov.tr/yayin/views/visitorPages/index.zul

24. Apay SE, Akpınar RB, Arslan S. Öğrencilerin cinsel mitlerinin incelenmesi. Anadolu Hemşirelik ve Sağlık Bilimleri Dergisi 2013; 16(2): 96-102.

25. Kukulu K, Gürsoy E, Ak SG. Turkish university students' beliefs in sexual myths. Sex Disabil 2009; 27: 49-59.

26. Derya YA, ve ark. Toplumsal cinsiyet rollerine ilişkin tutumların cinsel tabulara etkisi. GÜSBD 2017; 6(1): 1-8.

27. Ejder Apay SE, et al. Student comparison of sexual myths: two-country case. Sex Disabil 2013; 31(3): 249-262.

28. Golbasi Z, et al. Sexual Myths Scale (SMS): Development, validity and reliability in Turkey. Sex Disabil 2016; 34 (1): $75-87$.

29. Özsoy S, Bulut S. Cinsel sağlık bilgisi dersinin hemşirelik öğrencilerinin cinsel mitleri üzerine etkisi. Kadın Sağlığı Hemşireliği Dergisi 2017; 3(2): 54-67.

30. Aygin D, ve ark. Üniversitede okuyan kadın öğrencilerin cinsel mitler ile ilgili görüşleri. Androloji Bülteni 2017; 19(2): 44-49.

31. Ogur P, Utkualp N, Aydınoğlu N. Sağlık yüksekokulu öğrencilerinin cinsellikle ilgili inanışları. STED 2016; 25: 13-21.

32. Karabulutlu Ö. Üniversite öğrencilerinde cinsiyete göre cinsel mitler. STED 2018; 27(3): 155-164.

33. Baştürk S, Taştepe M. Evren ve örneklem. Bilimsel Araştırma Yöntemleri. Ankara: Vize Yayıncılık; 2013.

34. Torun F, Torun SD, Özaydın AN. Erkeklerde cinsel mitlere inanma oranları ve mitlere inanmayı etkileyen faktörler. Düşünen Adam Psikiyatri ve Nörolojik Bilimler Dergisi 2011; 24(1): 24-31.

35. Civil B, Yıldız H. Erkek öğrencilerin cinsel deneyimleri ve toplumdaki cinsel tabulara yönelik görüşleri. DEUHYO ED 2010, 3(2):58-64.

36. Bostancı N, ve ark. Üniversite öğrencilerinde cinsiyete göre cinsel mitler. 6. Ulusal Hemşirelik Öğrencileri Kongresi “Uluslararası Katılımlı" Kongre Özet Kitabı; 2007. p.156.

37. Aker S, Böke Ö. The effect of education on the sexual beliefs of family physicians. Int J Sex Health 2016; 28(1): 111-116.

38. Bamik H. Talking about sexual attitudes and behaviors; a cultural and social taboo in Afghanistan. Humanitarian and SocioEconomic Sciences Journal 2019; 3 (14):18-28.

39. Abdolmanafi A, et al. Culture and sexuality: Cognitive-emotional determinants of sexual dissatisfaction among Iranian and New Zealand women. J Sex Med 2018; 15(5): 687-697.

40. Cinsel Eğitim Tedavi ve Araştırma Derneği (CETAD). Cinsel Sağlık ve Üreme Sağlığı Araştırması. İstanbul: Organizasyon, 2006. 
41. Bozkurt S. Bireylerin cinsel mitlere inanma durumunun ve cinsel bilgi düzeylerinin incelenmesi. Yayınlanmamış Yüksek lisans Tezi, Üsküdar Üniversitesi Sosyal Bilimler Enstitüsü, 2016.

42. Kilci Ş. Evlilik hazırlığı yapan çiftlerin cinsel mitlere inanma durumları ve etkileyen faktörler. Aydın Adnan Menderes Üniversitesi Sağlık Bilimleri Enstitüsü, Yayınlanmamış Yüksek Lisans Tezi, 2018. 